Ganegodage, L.H., Waidyasekara, K.G.A.S. and Mallawaarachchi, H., 2021. Assessing the carbon emission reduction by grid-tied photovoltaic (PV) technology for buildings in Sri Lanka. In: Sandanayake, Y.G., Gunatilake, S. and Waidyasekara, K.G.A.S. (eds). Proceedings of the $9^{\text {th }}$ World Construction Symposium, 9-10 July 2021, Sri Lanka. [Online]. pp. 122-133. DOI: https://doi.org/10.31705/WCS.2021.11. Available from: https://ciobwcs.com/papers/

\title{
ASSESSING THE CARBON EMISSION REDUCTION BY GRID-TIED PHOTOVOLTAIC (PV) TECHNOLOGY FOR BUILDINGS IN SRI LANKA
}

\author{
L.H. Ganegodage ${ }^{1}$, K.G.A.S. Waidyasekara ${ }^{2}$ and Harshini Mallawaarachchi ${ }^{3}$
}

\begin{abstract}
Energy related carbon emission of buildings is a major cause of global warming. In order to mitigate energy related carbon emission, buildings tend to adopt renewable energy technologies. Amongst renewable energy technologies, grid-tied PV technology has gained the interest of building energy consumers as an alternative energy source. Nevertheless, there is considerably low implementation of grid-tied PV technology in Sri Lanka, especially as a carbon reduction strategy. A key reason for lack of implementation of grid-tied PV system is that majority of buildings still depend on traditional energy sources for their total energy needs. Hence, there is a need of highlighting the importance of grid-tied PV system to penetrate the existing traditional energy market. The aim of this study is therefore to assess the possible energy related carbon reduction of grid-tied PV system for buildings in Sri Lanka. Accordingly, total of four (4) buildings were selected as case studies, including two buildings with grid-tied $P V$ technology and two other buildings that are totally dependent on traditional energy sources. Subsequently, carbon footprint assessment was conducted to four (4) buildings specifying to energy related carbon emitting activities. And research findings revealed that selected two buildings with grid-Tied $P V$ technology achieve an average reduction of carbon by $3379.77 \mathrm{~kg}$ and $3013.06 \mathrm{~kg}$ respectively per month compared to traditionalenergy buildings. Consequently, this work has successfully identified that buildings with grid-tied PV technology achieve a reduction in energy related carbon emission compared to buildings with traditional energy sources.
\end{abstract}

Keywords: Buildings; Carbon footprint assessment; Carbon reduction; Grid-tied PV technology.

\section{INTRODUCTION}

World energy consumption is rapidly growing with the economic and population growth (Pérez-Lombard et al., 2008). Dincer (1999) stated that increasing traditional energy supply leads to environmental problems including air pollution, ozone depletion, radioactive emissions and forest degradation. Expressing similar view, Menyah et al. (2010) explained that traditional energy resources contribute to carbon dioxide emission, which continues to deteriorate the quality of environment. According to Khan et al.

\footnotetext{
${ }^{1}$ Department of Building Economics, University of Moratuwa, Sri Lanka, laknag@uom.lk

${ }^{2}$ Department of Building Economics, University of Moratuwa, Sri Lanka, anuradha@uom.lk

${ }^{3}$ Department of Building Economics, University of Moratuwa, Sri Lanka, harshinim@uom.lk
} 
(2020), energy consumption is a key driver of global carbon emission. Global warming has elevated by the ever-increasing energy related carbon emissions and this has grabbed the attention of both practitioners and academics (Zhang and Cheng, 2009). Accordingly, adoption of renewable energy technologies to achieve zero greenhouse gas emissions has come to the surface (Sardianou and Genoudi, 2013). Dovì et al. (2009) stated that development and implementation of renewable energy technologies offer several benefits, such as carbon emission reduction, cost saving and waste reduction to the user.

Amongst renewable energy sources, solar energy technologies have clear environmental benefits compared to traditional energy sources, thereby leading to sustainable energy generation (Tsoutsos et al., 2005). Consequently, energy users are influenced to adopt solar systems such as grid-tied PV technology to address shortfalls of conventional energy system (Boontome et al., 2017). However, there is considerably low implementation of grid-tied PV technology in Sri Lanka, especially as a carbon reduction strategy. Hence, this study focuses on assessing the energy related carbon reduction potential of grid-tied PV system for buildings in Sri Lanka. Accordingly, the aim of this research was to assess the possible energy related carbon emission reduction of grid-tied PV system in buildings in Sri Lanka. The paper structure begins with an introduction to the study, followed by a literature review on energy consumption, carbon emissions in buildings and PV technology. The research methodology, data collection, and data analysis are presented next, and finally, the paper presents conclusions derived from research findings with recommendations.

\section{LITERATURE REVIEW}

\subsection{ENERGY CONSUMPTION AND CARBON EMISSION OF BUILDINGS}

Building sector plays a major role in economy, accounting for about $40 \%$ of global energy consumption and over $30 \%$ of $\mathrm{CO}_{2}$ emissions (Yang et al., 2014). Similarly, Omer (2007) explains in his studies that globally, buildings accounts for about $40 \%$ of the world's total energy usage and offcie buildings accounts for a large portion of that relative to other sectors. The growth in population, increasing demand for building services and comfort levels, together with the rise in time spent inside buildings will influence the continuous improvement of the energy in buildings (Pérez-Lombard et al., 2008). Due to high energy consumption, building energy has become one of the major sources of carbon emission, which increase the environmental pollution by releasing large amount of carbon dioxide (González and García Navarro, 2006). According to Lu (2020), one-third from the total energy related carbon emissions emerge from the building sector. Further, authors suggest one way of reducing building energy related carbon emission is to adopt renewable energy sources as an alternative to conventional energy sources. Especially grid-tied PV technology has become one of the major renewable sources in energy industry since it reduces the emission of Green House Gas (GHG) and air pollution (Wang et al., 2017).

\subsection{GRID-TIED PV TeCHNOLOGY FOR CARBON EMISSION REDUCTION}

Madeti (2017) defines grid-tied PV technology as a system that contains electricity generating solar PV power system which is integrated to utility grid. Grid connected PV system ensures maximum use of energy from the utlity grid and solar power system itself (Karki et al., 2012). Figure 1 depicts the function of a grid-tied PV system, from the harvesting of solar energy by solar modules to the transmission of that energy to the local 
utility grid. Componenets of grid-tied PV system consist of PV arrays connected to the utility grid by means of power conditioning unit (Vázquez and Vázquez, 2018). This is alos known as the inverter, which is the primary component of grid-tied PV system (Bhatia, 2014). Further to author, the power conditioning unit converts the DC power into AC power generated by photovoltaic system to the required voltage and power quality. Grid-tied PV technology varies from different sizes such as small scale system (mostly rooftop and building integrated $\mathrm{PV}$, in $\mathrm{kW}$ ) for residential purposes and large scale systems (in megawatt size) for solar power stations (Parida et al., 2011). Grid-tied PV system offers range of benefits, especially positive environmental impact in terms of carbon emission (Gunerhan et al., 2008). Even government supports are excuted to promote worldwide power generated from grid-tied PV system to reduce the rising environmental and energy problems (He et al., 2012).

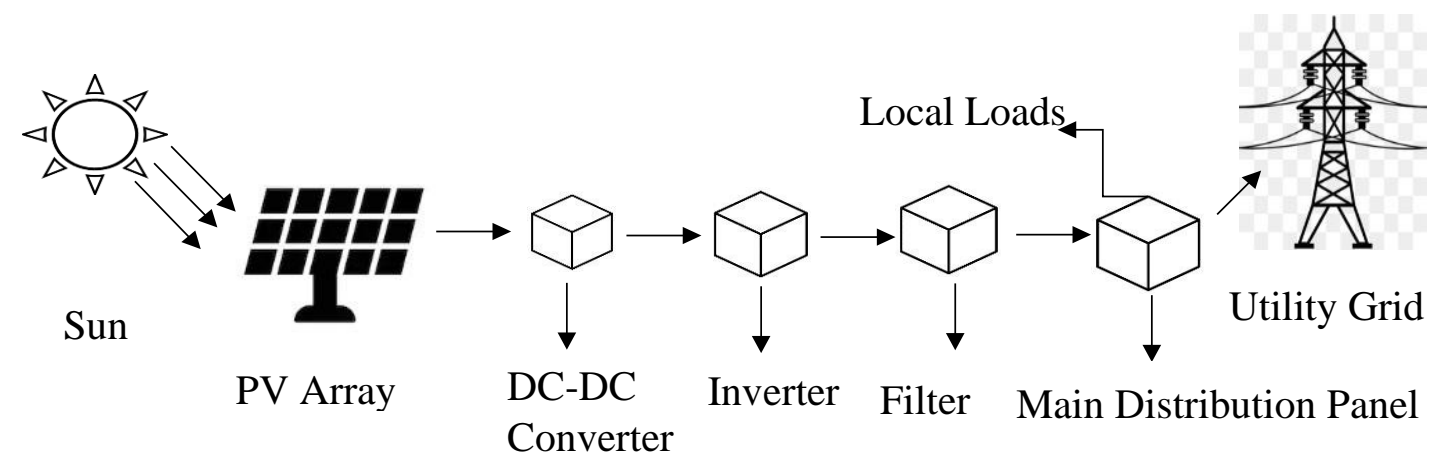

Figure 1: Grid-tied solar PV system (Source: Adaramola, 2014)

The driving force behind the use of clean and renewable energy is global energy demand and environmental concerns (Borges Neto et al., 2010). Authors further revealed that solar power as one of the inexhaustible and $\mathrm{CO}_{2}$ free sources of energy in the world. Solar energy could play a significant part in greening the energy portfolio of the nation (Sarzynski et al., 2012). Solar photovoltaic power generation is generally considered as one of the most desirable renewable energy sources due to its immense capacity to reduce air pollution and energy usage (Hosenuzzaman et al., 2015). Authors declared that there are zero release of $\mathrm{CO}_{2}, \mathrm{NO}_{\mathrm{x}}$ and $\mathrm{SO}_{2}$ emission during $\mathrm{PV}$ system operation and it does not contribute to global warming. The PV industry's technological advances derive from attempts to lessen greenhouse gas emissions and abide by existing sustainable development principles (Bakhiyi et al., 2014). Accordingly, authors explain that compared to fossil fuels, the PV industry is an ideal contributor to reducing greenhouse gas emission and to control carbon footprint of worldwide entities. Even, organisations are currently concern about their carbon footprint which motivate them to adopt renewable energy technologies to assess and reduce their carbon footprint (Lenzen et al., 2010).

\subsection{AsSESSMENT OF ORganisational CARbon FootPrint}

Carbon footprint is total emission from organisation, company, or a person expressed in terms of carbon dioxide and can be measured primarily for organisations, individuals, countries and products (Wiedmann and Minx, 2007). All types of organisations affect global carbon emission; therefore, calculation of organisation's carbon footprint is beneficial for managing the environmental impact (Robinson et al., 2018). Especially, carbon footprint assessment enables organisations to assess their carbon impact after an 
implementation of carbon reduction strategies such as renewable energy technologies (Robinson et al., 2018). Awanthi et al. 2018 explained that in addition to quantifying the organisation carbon emission, assessment of carbon footprint allows organisation to identify and target reduction from its emission sources.

ISO 14064 and GHG protocol are the two key internationally accessible standards that can be adopted by organisations for carbon footprint assessment (Gao et al., 2013). According to ISO 16064, the key steps of calculating organisational carbon footprint can be identified as follows:

- Definition of organisation boundaries: Determines which proportion of the organisation is included in calculation of CFP (Carbon Footprint).

- Establishing operational boundaries: Establishment of operational boundaries recognize GHG emissions and removals regarding organisation's operations. In here GHG emissions and removals categorized into three scopes as direct emission, energy indirect emission and other indirect emissions.

- Calculation of CFP: Within established boundaries accurate consumption data should be collected.

- Reporting and verifying: It requires organisation to prepare report in order to facilitate inventory verification, participation in a GHG program, or to inform external or internal users.

According to ISO 14064, first step of organisational carbon footprint assessment is to define organisation boundaries followed by determining operational boundaries. When considering operational boundaries, ISO 14064 and GHG protocol divide GHG emission into three sources, such as scope 1, scope 2 and scope 3 (Ozawa-Meida et al., 2013). According to the standards, three (3) defined scopes of carbon emission can be displayed in Table 1. This study only focuses on scope one and two covering the energy related carbon emission of buildings.

Table 1: Three scopes of carbon emission

\begin{tabular}{cl}
\hline Scope & \multicolumn{1}{c}{ Scope Definition } \\
\hline Scope 01 & $\begin{array}{l}\text { Direct GHG emission caused by sources that are owned or controlled by the } \\
\text { company }\end{array}$ \\
Scope 02 & $\begin{array}{l}\text { Indirect carbon emission, that is GHG emission from generation of } \\
\text { purchased electricity consumed by the organisation. }\end{array}$ \\
Scope 03 & Other indirect emissions and it is an optional reporting category \\
\hline
\end{tabular}

(Source: Matthews et al., 2008)

After determining the organisational and operational boundaries carbon footprint calculation is conducted. According to Intergovernmental Panel on Climate Change (2006), CFP can be calculated based on common simple methodological approach. ISO 14064 explains that the carbon footprint can be calculated by simply GHG activity data multiplied by GHG emission factors. Activity Data (AD) is the data collected related to the energy direct, indirect and other indirect activities. The emission factors published in different sources can be found and used as Emission Factor (EF) in carbon assessment (Intergovernmental Panel on Climate Change, 2006). Accordingly, in this research carbon footprint was calculated based on the above calculation method introduced under ISO 14064. This basic calculation method is further used in study conducted on Sri Lanka 
carbon footprint of an organisation: a case study, faculty of agriculture, university of Ruhuna (Awanthi and Navaratne, 2012). This equation is presented in the methodology section as Equation 01.

\section{METHODOLOGY}

This research uses the case study research strategy for achieving the research aim; to assess the possible energy related carbon reduction of grid-tied PV system in buildings in Sri Lanka. Multiple case study design was adopted. Accordingly, four (4) buildings were selected as case studies, including two buildings with grid-tied PV technology and two other buildings that are totally dependent on traditional energy sources. Two types of buildings have been chosen to make it easier to compare carbon emissions from buildings with grid-tied PV system and buildings with traditional energy sources. Criteria considered in case selection are presented in Table 2.

Table 2: Criteria considered in case selection

\begin{tabular}{|c|c|c|c|c|}
\hline & Case A & Case B & Case C & Case D \\
\hline Type of Building & Office Building & $\begin{array}{l}\text { Office } \\
\text { Building }\end{array}$ & $\begin{array}{l}\text { Office } \\
\text { Building }\end{array}$ & $\begin{array}{l}\text { Office } \\
\text { Building }\end{array}$ \\
\hline Location & Colombo 02 & Colombo 02 & Colombo 03 & Colombo 11 \\
\hline Number of floors & 12 & 11 & 10 & 13 \\
\hline Height of floor (ft) & $12 \mathrm{ft}$ & $12 \mathrm{ft}$ & $12 \mathrm{ft}$ & $12 \mathrm{ft}$ \\
\hline $\begin{array}{l}\text { Floor area of the } \\
\text { building }\left(\mathrm{m}^{2}\right)\end{array}$ & $\begin{array}{l}7900 \mathrm{~m}^{2} \text { per } \\
\text { floor }\end{array}$ & $\begin{array}{l}7500 \mathrm{~m}^{2} \text { per } \\
\text { floor }\end{array}$ & $\begin{array}{l}5200 \mathrm{~m}^{2} \text { per } \\
\text { floor }\end{array}$ & $\begin{array}{l}8500 \mathrm{~m}^{2} \text { per } \\
\text { floor }\end{array}$ \\
\hline Number of occupants & 620 & 650 & 650 & 620 \\
\hline $\begin{array}{l}\text { Source of power } \\
\text { supply }\end{array}$ & $\begin{array}{l}\text { Grid-tied PV } \\
\text { technology, } \\
\text { utility grid and } \\
\text { standby power }\end{array}$ & $\begin{array}{l}\text { Grid-tied PV } \\
\text { technology, } \\
\text { utility grid } \\
\text { and standby } \\
\text { power }\end{array}$ & $\begin{array}{l}\text { Utility grid } \\
\text { and standby } \\
\text { power }\end{array}$ & $\begin{array}{l}\text { Utility grid } \\
\text { and standby } \\
\text { power }\end{array}$ \\
\hline
\end{tabular}

Within the selected cases, document review and semi structured interviews were conducted to collect the data. Organisational CFP assessment guidelines, electricity bill documents, records of diesel consumption of generator and power generation record documents of solar panels were reviewed with respect to documents. Power consumption data was readily available for $2017 / 2018$ period. Hence, 2017/2018 period was considered when reviewing documents such as electricity bill documents, records of diesel consumption of generator and power generation record documents of solar panels. Accordingly, in this study carbon footprint assessment base year was considered as 2017/2018. The interview guideline was used in conducting semi structured interviews, where two respondents from each case were selected according to their role performed (one managerial level respondent and one executive level respondent in each case). The collected data from case studies were analysed using carbon footprint assessment procedure based on ISO 14064. Hence, under carbon footprint assessment, Equation 01 was used to calculate the carbon footprint.

$$
\text { Carbon foot print }(C F P)=\text { Activity Data }(A D) \times \text { Emission Factor }(E F)
$$


Carbon footprint was measured in kilograms (kg). Identified Activity Data (AD) of this study are average monthly electricity consumption, average diesel consumption, monthly average power generation of solar panels. Equations 02, 03 and 04 were used to compute the aforementioned activity data.

$$
\begin{aligned}
& \text { Average monthly electricity consumption }=\frac{\text { Total electricity Consumption }(\mathrm{kWh})}{\text { Number of Months }} \\
& \text { Average monthly diesel Consumption }=\frac{\text { Total Diesel Consumption }(\text { liter })}{\text { Number of Months }} \\
& \text { Monthly average solar power generation }=\frac{\text { Total Solar Power generation }(\mathrm{kWh})}{\text { Number of months }}
\end{aligned}
$$

Accordingly, average monthly electricity consumption, diesel consumption and solar power generation were calculated by dividing total consumptions for the year by number of months per year. Subsequently, emission factors (EF) were developed using published data by Sri Lanka Sustainable Energy Authority (SEA). Emission factors were presented in kilograms of carbon dioxide per one unit of activity data. The emission factors considered for this study are displayed in Table 3 explicating the amount of carbon dioxide emitted from diesel and electricity.

Table 3: Carbon dioxide emitted from diesel and electricity

\begin{tabular}{lcc}
\hline \multicolumn{1}{c}{ Fuel } & Unit & $\mathbf{C O}_{2}$ emission \\
\hline Electricity & $\mathrm{kg} / \mathrm{kWh}$ & 0.71 \\
Diesel & $\mathrm{kg} / \mathrm{l}$ & 2.74 \\
\hline
\end{tabular}

Finally, the results of carbon footprint assessment were used to indicate the potential carbon reduction of grid-tied PV system compared to buildings with traditional energy sources. The key findings derived through case analysis are presented below.

\section{FINDINGS AND DISCUSSION}

\subsection{ASSESSMENT OF CARbON FoOTPRINT}

Assessment of carbon footprint was conducted for two (2) buildings with grid-tied PV technology and two (2) buildings with traditional energy sources. Two types of buildings were selected to facilitate comparison between carbon emission of grid-tied PV system and traditional energy sources. The selected organisations are aware of building carbon emissions and the respondents stated that they are familiar with the concept of assessment of carbon footprint. However, as per the respondents, they do not conduct carbon assessment for their respective organisations due to time, labour and cost constraints. The respondents further emphasised that lack of interest of managers on carbon assessment and lack of carbon reduction projects within the organisation as an added reasons for the absence of carbon assessment. Hence, interviewees acknowledged that there is a lack of understanding of organisation's carbon emissions.

In this study, carbon footprint assessment was only conducted for energy related emission activities (Refer section 2.3). Accordingly, data analysis and findings of carbon footprint assessment for each case study are designed under two structured steps as follows. 
- Step 1 - Calculation of total energy use

As the first step of building carbon footprint assessment, energy sources and their respective consumptions were identified under the calculation of total energy use. Thus, the findings and discussion of the total energy use is further discussed in Section 4.2

- Step 2 - Assessment of Carbon emission

Based on the total energy use calculated (Step 01), carbon footprint was calculated for all 04 buildings under the section of carbon emission assessment (Step 02). Accordingly, the findings and discussion of the carbon emission assessment is elaborated in Section 4.3.

\subsection{Calculation of TOTAl Energy USE}

Energy sources and their total electricity consumption of each case was identified as the first step of carbon footprint calculation. Table 4 summarises the energy sources consumed by the selected cases.

Table 4: Energy Sources of the Selected Cases

\begin{tabular}{lcccc}
\hline \multicolumn{1}{c}{ Energy Sources } & Case A & Case B & Case C & Case D \\
\hline Diesel Generator & $\checkmark$ & $\checkmark$ & $\checkmark$ & $\checkmark$ \\
Utility Grid & $\checkmark$ & $\checkmark$ & $\checkmark$ & $\checkmark$ \\
Grid-Tied PV Technology & $\checkmark$ & $\checkmark$ & - & - \\
\hline
\end{tabular}

According to the data presented in Table 4, Cases A and B use grid-tied PV technology as an energy source along with diesel generator and utility grid. And in Cases C and D, total energy consumption depends on diesel generator and public utility grid. As a result, as shown in Table 4, the energy consumption of Cases C and D is totally dependent on traditional energy sources whereas the total energy consumption in Cases A and B is a mix of traditional and renewable sources. Considering the identified energy sources, average monthly energy consumption of each source was measured in order to calculate the total energy consumption of selected cases, which is summarised and displayed in Table 5.

Table 5: Total electricity consumption of the cases

\begin{tabular}{lllll}
\hline & \multicolumn{2}{c}{$\begin{array}{c}\text { Buildings with Grid-Tied } \\
\text { PV Technology }\end{array}$} & \multicolumn{2}{c}{$\begin{array}{c}\text { Buildings without Grid-Tied } \\
\text { PV Technology }\end{array}$} \\
\cline { 2 - 5 } & \multicolumn{1}{c}{ Case A } & \multicolumn{1}{c}{ Case B } & \multicolumn{1}{c}{ Case C } & \multicolumn{1}{c}{ Case D } \\
\hline $\begin{array}{l}\text { Generator Diesel } \\
\text { Consumption }\end{array}$ & 26.25 litres & 100 litres & 37.33 litres & 3810.8 litres \\
Utility Grid & 144508.08 & $30838 \mathrm{kWh}$ & $13835.41 \mathrm{kWh}$ & $576480 \mathrm{kWh}$ \\
& $\mathrm{kWh}$ & & & - \\
Grid-Tied PV & $4760.24 \mathrm{kWh}$ & 4243.75 & - & \\
Technology & & $\mathrm{kWh}$ & & \\
Monthly Average Total & 26.25 litres + & 100 litres + & 37.33 litres + & 3810.8 litres + \\
Energy Consumption & 149268.32 & 35081.75 & $13835.41 \mathrm{kWh}$ & $576480 \mathrm{kWh}$ \\
& $\mathrm{kWh}$ & $\mathrm{kWh}$ & & \\
\hline
\end{tabular}

According to Table 5, diesel consumption was omitted in total electricity calculation (as the diesel consumption calculated in litres is only used for carbon emission calculation). 
The utility grid consumption and the electricity generated by solar panels were only considered in calculating total electricity consumption. Thus, the total energy consumption indicated in Kilowatt hour $(\mathrm{kWh})$ along with generator's diesel consumption in litres as presented in Table 5.

\subsection{ASSESSMENT OF CARbON EMISSION}

Carbon emission assessment was conducted by calculating carbon footprint of total energy use of selected buildings. Amount of carbon emission $(\mathrm{kg})$ from energy consumption $(\mathrm{kWh})$ of buildings were calculated by carbon footprint assessment. Further, carbon emissions by energy consumption derived from carbon footprint equation (Equation 01) presented in methodology section. Calculated energy based monthly average carbon emissions for selected cases are presented in Figure 2.

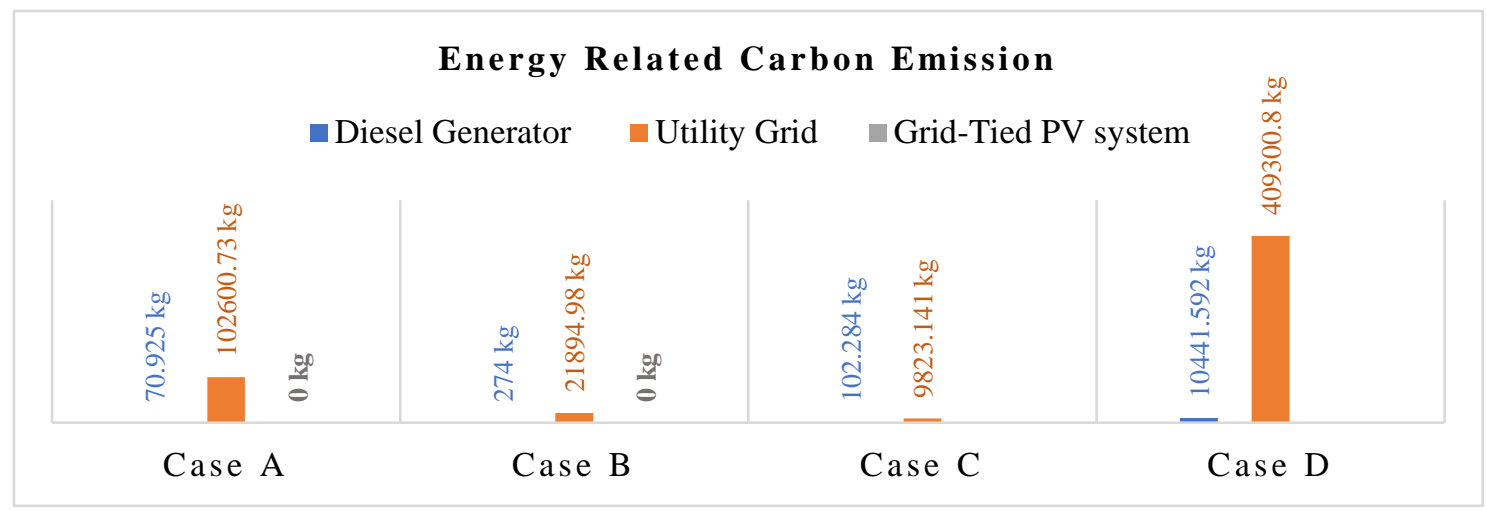

Figure 2: Energy related total carbon emission of the cases

Figure 2 presents the carbon emission generated by each energy sources of the cases. Accordingly, Cases A and B emit carbon from both diesel generator and utility grid while achieving zero carbon emission from grid-tied PV technology. Moreover, Cases C and D emit carbon from all the utilised energy sources; diesel generator and utility gird as indicated in Figure 2. In all four cases, diesel generator and utility grid emit carbon dioxide in the process of generating energy. This is because, as shown in Table 3, each unit of electricity and diesel consumption emit $0.71 \mathrm{~kg}$ and $2.74 \mathrm{~kg}$ of carbon dioxide, respectively.

Compared to Cases C and D, the energy sources of Cases A and B include a grid-tied PV system, which generates energy by extracting solar energy. Therefore, portion of the total energy of Cases A and B are produced with renewable energy technology. And the application of renewable energy system support Cases A and B to generate renewable energy without emitting carbon emission. Accordingly, as presented in Table 5, grid-tied PV systems of Cases A and B generate $4760.24 \mathrm{kWh}$ and $4243.75 \mathrm{kWh}$ respectively, which have zero impact on carbon emission (Figure 2).

Nevertheless, the energy mix of Cases C and D comprise of utility grid and diesel generator. Accordingly, the total energy demand is entirely catered by conventional energy sources. Therefore, the energy sources of Cases C and D actively participate in carbon emission, as shown in Figure 2. 


\subsection{Potential of Carbon Emission Reduction}

Calculation of total energy use and assessment of carbon footprint, enable to determine the potential for carbon emission reduction of grid-tied PV system. Under the calculation of total energy use, three different energy sources were identified in Table 4. In addition to conventional energy sources, Cases A and B use grid-tied PV technology as a renewable energy source to support their energy demand. This combination of renewable (grid-tied PV system) and non-renewable (local grid) energy can be elaborated as shown in Figure 3. According to Figure 3, Cases A and B incorporate solar energy to their energy supply, leading to energy saving of $4760.24 \mathrm{kWh}(3 \%)$ and $4243.75 \mathrm{kWh}(12 \%)$ respectively from total electricity generation. This portion of power generation considered as renewable with zero carbon emission. Furthermore, as shown in Figure 3, the remaining energy demand of Cases A and B, which is $149268.32 \mathrm{kWh}(97 \%)$ and $35081.75 \mathrm{kWh}(89 \%)$ are catered by local utility grid. This is subjected to energy related carbon emission.
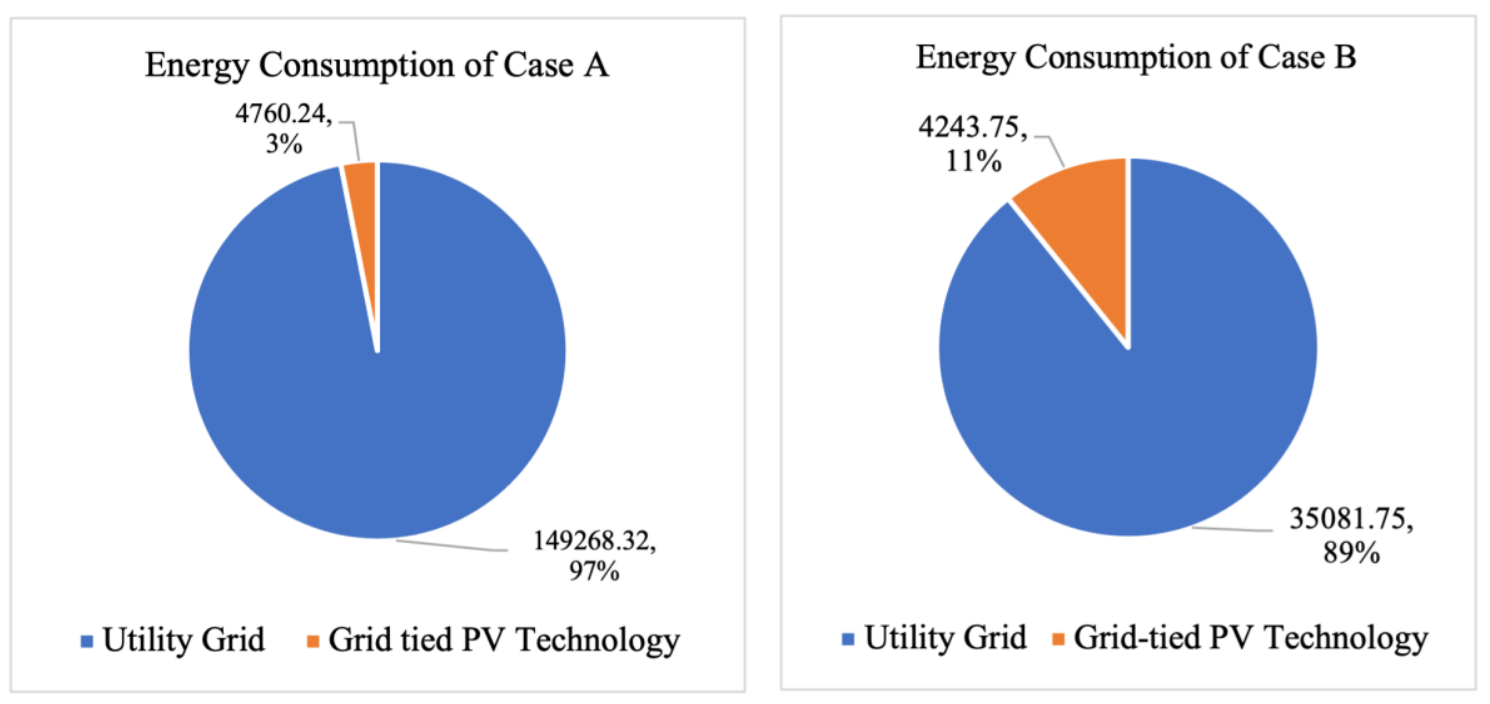

Figure 3: Energy consumption of cases $A$ and B

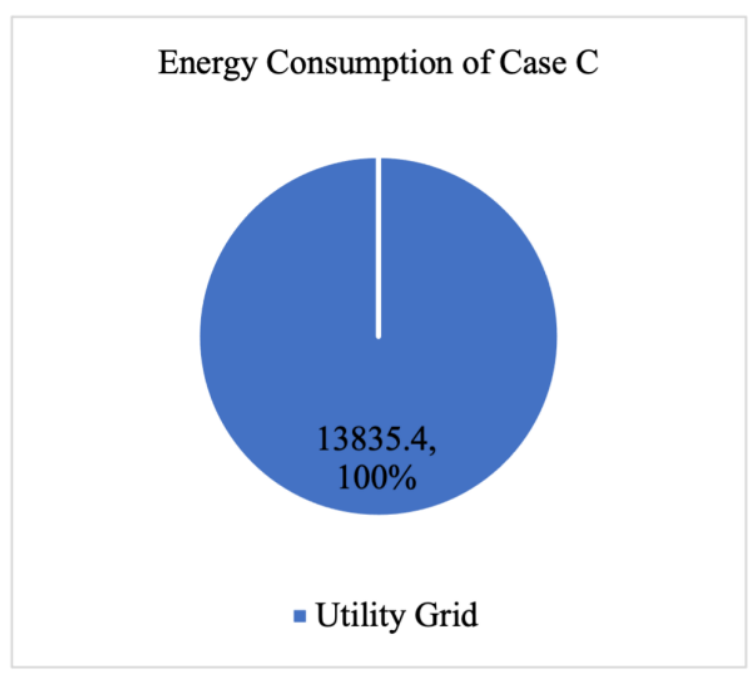

\section{Energy Consumption of Case D}

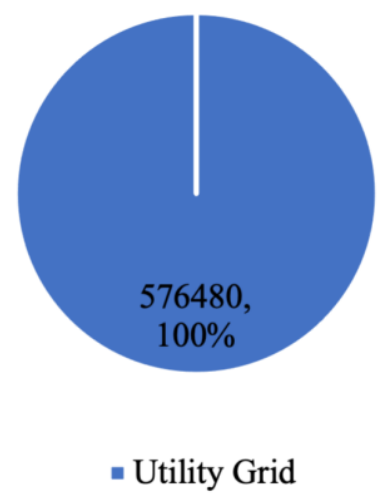

Figure 4: Energy consumption of cases $C$ and $D$ 
However, Cases C and D rely their total energy consumption on traditional energy sources, which does not support any energy or carbon reduction. This can be further elaborated using the pie charts given in Figure 4. Accordingly, Cases $\mathrm{C}$ and D rely on traditional energy systems (100\%), which leads to maximum carbon emission without any possible reduction. Therefore, compared to Cases $\mathrm{A}$ and $\mathrm{B}, \mathrm{Cases} \mathrm{C}$ and $\mathrm{D}$ have more impact on environment in terms of energy related carbon emission.

The carbon reduction from grid-tied PV system can also be elaborated in following way. If it is assumed the generated electricity by grid-tied PV technology is purchased by grid, it gives arise to carbon emission since it is non-renewable energy source. This can be further described using Table 6. According to Table 6, solar panel of Cases A and B generate electricity of $4760.24 \mathrm{kWh}$ and $4243.75 \mathrm{kWh}$ respectively and has zero impact on carbon emission.

Table 6: Carbon emission of $A$ and $B$ if $P V$ energy is purchased by grid

\begin{tabular}{cccc}
\hline $\begin{array}{c}\text { Case } \\
\text { Building }\end{array}$ & $\begin{array}{c}\text { Energy Produced by Grid-Tied } \\
\text { PV technology (Assume this } \\
\text { amount is purchased by grid) }\end{array}$ & Emission factor & Carbon emission \\
\hline Case A & $4760.24 \mathrm{kWh}$ & 0.71 & 3379.77 \\
Case B & $4243.75 \mathrm{kWh}$ & 0.71 & 3013.06 \\
\hline
\end{tabular}

Table 6 shows if the electricity produced by grid-tied PV technology is purchased by grid, it will be subjected to emission factor of $0.71 \mathrm{~kg} / \mathrm{kwh}$. Subsequently, carbon emission will be $3379.77 \mathrm{~kg}$ per month for Case A and $3013.06 \mathrm{~kg}$ per month for Case B. Therefore, with the implementation of grid-tied PV system, Cases A and B have gained a reduction of carbon emission by $3379.77 \mathrm{~kg}$ and $3013.06 \mathrm{~kg}$ per month. Therefore, this again prove the potential of grid-tied PV technology to minimise the impact of building's carbon emission.

\section{CONCLUSIONS}

It was revealed that compared to traditional-energy buildings, grid-tied PV buildings obtain reduction in energy and carbon emission for the building. Two buildings with gridtied PV technology indicate energy saving of $4760.24 \mathrm{kWh}(3 \%)$ and $4243.75 \mathrm{kWh}(12 \%)$ respectively from monthly total energy of the building. In addition, due to the energy saving, both buildings achieved a reduction of carbon by $3379.77 \mathrm{~kg}$ and $3013.06 \mathrm{~kg}$ respectively per month. Consequently, this work has successfully identified that buildings with grid-tied PV technology can achieve a huge reduction in energy related carbon emission compared to buildings with traditional energy sources.

In spite of the detailed assessment of the possible energy related carbon reduction of gridtied PV system for buildings in Sri Lanka, some limitations are still presented in this paper. First, the sample size of the survey in this study is relatively small. Thus, cautions should be given when the analysis results are interpreted. Second, the calculation of carbon emission was limited to energy related activities. Third, findings from this study apply to office buildings in Sri Lanka exclusively, which may vary in other different locations, sectors and countries. Despite these limitations, this study is still valuable, since it delivers an understanding of potential carbon reduction of the grid-tied PV buildings compared to the traditional-energy buildings of Sri Lanka. For further research actions, 
potential carbon reduction of grid-tied PV system can be studied in other sectors of Sri Lanka.

Further, it is recommended that steps can be taken to enhance the implementation of gridtied PV system in Sri Lanka's built environment. And the energy consumers need to be made aware of carbon reduction potential of the grid-tied PV system. In Sri Lanka, energy consumers are becoming increasingly interested in reducing energy related carbon emission to reduce environmental impact. Thus, government can financially assist the new PV users to penetrate the solar PV market by introducing capital subsidies. Therefore, buildings can actively participate on reducing energy related carbon emission and thereby contribute to the betterment of Sri Lanka.

\section{REFERENCES}

Adaramola, M., 2014. Viability of grid-connected solar PV energy system in Jos, Nigeria. International Journal of Electrical Power \& Energy Systems, 61, pp. 64-69.

Awanthi, M., and Navaratne, C., 2012. Carbon footprint of an organization: A case study, Faculty of Agriculture, University of Ruhuna. In Proceedings of International Forestry and Environment Symposium, 15(0).

Awanthi, M. and Navaratne, C., 2018. Carbon footprint of an organization: A tool for monitoring impacts on global warming. Procedia Engineering, 212, pp.729-735.

Bakhiyi, B., Labrèche, F., and Zayed, J., 2014. The photovoltaic industry on the path to a sustainable future - Environmental and occupational health issues. Environment International, 73, pp. 224-234.

Bhatia, S., 2014. Solar photovoltaic systems. Advanced Renewable Energy Systems, pp. 144-157.

Boontome, P., Therdyothin, A., and Chontanawat, J., 2017. Investigating the causal relationship between non-renewable and renewable energy consumption, $\mathrm{CO}_{2}$ emissions and economic growth in Thailand. Energy Procedia, 138, pp. 925-930.

Borges Neto, M., Carvalho, P., Carioca, J. and Canafístula, F., 2010. Biogas/photovoltaic hybrid power system for decentralized energy supply of rural areas. Energy Policy, 38(8), pp.4497-4506.

Dincer, I., 1999. Environmental impacts of energy. Energy Policy, 27(14), pp. 845-854.

Dovì, V., Friedler, F., Huisingh, D., and Klemeš, J., 2009. Cleaner energy for sustainable future. Journal of Cleaner Production, 17(10), pp. 889-895.

Gao, T., Liu, Q. and Wang, J., 2013. A comparative study of carbon footprint and assessment standards. International Journal of Low-Carbon Technologies, 9(3), pp. 237-243.

González, M.J., and García Navarro, J., 2006. Assessment of the decrease of CO2 emissions in the construction field through the selection of materials: Practical case study of three houses of low environmental impact. Building and Environment, 41(7), pp. 902-909.

Gunerhan, H., Hepbasli, A., and Giresunlu, U., 2008. Environmental Impacts from the Solar Energy Systems. Energy Sources, 31(2), pp. 131-138.

He, F., Zhao, Z. and Yuan, L., 2012. Impact of inverter configuration on energy cost of grid-connected photovoltaic systems. Renewable Energy, 41, pp. 328-335.

Hosenuzzaman, M., Rahim, N., Selvaraj, J., Hasanuzzaman, M., Malek, A. and Nahar, A., 2015. Global prospects, progress, policies, and environmental impact of solar photovoltaic power generation. Renewable and Sustainable Energy Reviews, 41, pp. 284-297.

Karki, P., Adhikary, B. and Sherpa, K., 2012. Comparative study of grid-tied photovoltaic (PV) system in Kathmandu and Berlin using PVsyst. 2012 IEEE Third International Conference on Sustainable Energy Technologies (ICSET), 2012, pp. 196-199.

Khan, M., Khan, M. and Rehan, M., 2020. The relationship between energy consumption, economic growth and carbon dioxide emissions in Pakistan. Financial Innovation, 6(1).

Lenzen, M., Wood, R., and Wiedmann, T., 2010. Uncertainty analysis for multi-region input-output models - A case study of the UK's carbon footprint. Economic Systems Research, 22(1), pp. 43-63. 
Lu, M. and Lai, J., 2020. Review on carbon emissions of commercial buildings. Renewable and Sustainable Energy Reviews, 119, pp. 109545.

Madeti, S.R., and Singh, S., 2017. Online modular level fault detection algorithm for grid-tied and off-grid PV systems. Solar Energy, 157, pp. 349-364.

Matthews, H.S., Hendrickson, C.T., and Weber, C.L., 2008. The Importance of Carbon Footprint Estimation Boundaries. Environmental Science \& Technology, 42(16), pp. 5839-5842.

Menyah, K., and Wolde-Rufael, Y., 2010. Energy consumption, pollutant emissions and economic growth in South Africa. Energy Economics, 32(6), pp. 1374-1382.

Omer, A.M., 2007. Renewable Energy Technologies, Sustainable Development, and Environment. Sustainable Development, 12(9), pp. 971-1008.

Ozawa-Meida, L., Brockway, P., Letten, K., Davies, J. and Fleming, P., 2013. Measuring carbon performance in a UK University through a consumption-based carbon footprint: De Montfort University case study. Journal of Cleaner Production, 56, pp. 185-198.

Parida, B., Iniyan, S. and Goic, R., 2011. A review of solar photovoltaic technologies. Renewable and Sustainable Energy Reviews, 15(3), pp. 1625-1636.

Pérez-Lombard, L., Ortiz, J. and Pout, C., 2008. A review on buildings energy consumption information. Energy and Buildings, 40(3), pp. 394-398.

Robinson, O. J., Tewkesbury, A., Kemp, S. and Williams, I. D., 2018. Towards a universal carbon footprint standard: A case study of carbon management at universities. Journal of Cleaner Production, 172, pp. 4435-4455.

Sardianou, E., and Genoudi, P., 2013. Which factors affect the willingness of consumers to adopt renewable energies? Renewable Energy, 57, pp. 1-4.

Sarzynski, A., Larrieu, J., and Shrimali, G., 2012. The impact of state financial incentives on market deployment of solar technology. Energy Policy, 46, pp. 550-557.

Tsoutsos, T., Frantzeskaki, N., and Gekas, V., 2005. Environmental impacts from the solar energy technologies. Energy Policy, 33(3), pp. 289-296.

Vázquez, N., and Vázquez, J., 2018. Photovoltaic System Conversion. Power Electronics Handbook, pp. 767-781.

Wang, Y., Ren, B., and Zhong, Q.C., 2017. Bounded-voltage Power Flow Control for Grid-tied PV Systems. 50(1), pp. 7699-7704.

Wiedmann, T., and Minx, J., 2007. Definition of carbon footprint [Online]. Available from: http://www.isaresearch.co.uk/ [Accessed 30 May 2021].

Yang, L., Yan, H. and Lam, J., 2014. Thermal comfort and building energy consumption implications - A review. Applied Energy, 115, pp. 164-173.

Zhang, X., and Cheng, X., 2009. Energy consumption, carbon emissions, and economic growth in China. Ecological Economics, 68(10), pp. 2706-2712. 